\title{
sciendo
}

\section{Universalism values and organisational citizenship behaviour referring to employee perception of corporate social responsibility}

\author{
Živilè STANKEVIČIŪTĖ \\ Kaunas University of Technology \\ Gedimino g. 50, LT-44249 Kaunas, Lithuania \\ Zivile.stankeviciute@ktu.lt \\ Wioletta WEREDA \\ Military University of Technology \\ Sylwestra Kaliskiego 2, 01-476, Warsaw, Poland \\ weredawioletta@tlen.pl
}

\begin{abstract}
Over the past decade, the number of studies investigating corporate social responsibility (CSR), its drivers and benefits has been growing. However, several gaps still remain. Previous research mostly investigated customer perceptions of CSR, leaving the employee perceptions in the sidelines and accordingly neglecting the employee importance. Furthermore, although acknowledging that employee perception of CSR is beneficial for the organisation, most of the previous studies have focused on employee attitudes as a desirable outcome forgetting about the employee behaviour, including organisational citizenship behaviour (OCB), which can be a source of competitive advantage. Moreover, although values have been recognised as key determinants of human attitudes and behaviour, it seems that the potential of values, including the universalism values, for driving the employee perception of CSR and OCB has not been revealed. Trying to close the gap, the paper aims at revealing the relationship between the employee perceptions of CSR, employee OCB and universalism values. In doing this, quantitative data were collected (301 responses in total). Consistent with the expectations, the survey indicated that employee perceptions of CSR directed at four main stakeholder groups, namely employees, customers, government, and social and non-social stakeholders had a positive effect on OCB. As it was expected, universalism values drive both the employee perception of CSR and employee OCB. Moreover, the findings support the idea that the employee perception of CSR partly mediates the relationship between the universalism values and OCB. Generally, the obtained results highlight the necessity for organisations to invest not only in CSR, but also in employee perceptions of CSR, as this could drive extra-role employee behaviour, namely OCB.
\end{abstract}

Keywords: corporate social responsibility; organisational citizenship behaviour; employee perceptions; values; universalism values; social identity theory, stakeholders.

Please cite the article as follows: Stankevičiūtè, Z., Wereda, W., (2020), "Universalism values and organisational citizenship behaviour referring to employee perception of corporate social responsibility", Management \& Marketing. Challenges for the Knowledge Society, Vol. 15, No. 2, pp. 302-325, DOI: 10.2478/mmcks-2020-0018.

\section{Introduction}

Nowadays, the internal and external business environments are changing more rapidly than ever before. In response, the organisations willing to survive in the long-term have to find new ways to re-create and enhance the competitive advantage. Given this 
necessity, increasingly more organisations commit to socially responsible practices, acknowledging that corporate social responsibility (CSR) drives company-favourable outcomes and reaps the greatest benefits for organisations (Bhattacharya and Sen, 2004; Bhattacharya et al., 2009; Peloza and Shang, 2011; Kong et al., 2020; Matten and Moon, 2020; Nguyen et al., 2020). Generally, CSR refers to the relationship between organisations and society, which denotes the organisation's actions to balance the financial performance, impact on society and impact on environment (Park and Levy, 2014). Thus, the idea that organisations take into account the interests of all stakeholders above and beyond shareholders is at the core of CSR (Hofman and Newman, 2014; Newman et al., 2015). In doing this, the organisations may engage in various practices of CSR. However, the response of a particular stakeholder relies on the way the practices are perceived by them, rather than on particular initiatives being implemented. This paper limits its focus on employee perception of CSR as studies in this field are still scant (Lee at al., 2012; Lee et al. 2013; Park and Levy, 2014; Hejjas et al., 2019; John et al., 2019; Asante Boadi et al., 2019) in respect to the literature analysing customer perspective (Öberseder et al., 2014; Park et al., 2014; Moisescu, 2015; González-Rodríguez and Díaz-Fernández, 2020). Meanwhile, employees are relatively highly salient stakeholders to whom the organisation owes a perfect duty (Greenwood, 2007).

Referring to the notion that employee perception of CSR causes benefits for the organisation, it is relevant to understand these outcomes. Despite the growing number of the related studies, the focus is mainly on the examination of the way the employee perception of CSR influences the employee attitudes, such as organisational commitment (Bramer et al., 2007, Hofman and Newman, 2014) or job satisfaction (Valentine and Fleischman, 2008). Nevertheless, the impact of CSR on employee behaviour, including OCB, has been largely neglected and remains underdeveloped (Carmeli et al., 2007; Rupp et al., 2013; Zhang et al., 2014; Newman et al., 2015; Farid et al., 2019; He et al., 2019). Generally, OCB refers to employee behaviours that go beyond the role requirements, that are not explicitly or directly recognised by the formal reward system, and that facilitate organisational functioning (Bolino et al., 2002; Organ, 1988). Drawing on Organ's (1998) fundamental assumption and later supporting empirical evidences that OCB enhances organisational performance (Podsakoff et al., 2000), the paper argues for the necessity to explore the mentioned behaviour, especially as it is also considered important to the organisation's sustainability (Lin et al., 2010). Although CSR is well recognised in the previous literature as the driver of employee attitudes, the question still remains how employee behaviour, in terms of OCB, may be driven by CSR perceived by employees. The paper seeks to close this gap analysing the relationship between the employee perceptions of CSR and OCB.

Turning to employee perception of CRS, not less important is to understand the factors, which determine the perception of a particular employee. In doing this, the paper refers to values, as values are used to characterise individuals and explain the motivational bases of attitudes and behaviour (Schwartz, 2015). Although different researchers have applied value theories to analyse the company performance, just a few studies have examined the effect of values on CSR (Choongo et al., 2018). By closing this gap, the paper, drawing on Schwartz's value theory, explores the impact of universalism values on employee OCB. Although Schwartz's value theory consists of 10 dimensions of values, the paper limits its focus to one dimension only, namely the universalism values. According to Schwartz (2012), universalism values derive from the survival needs of individuals and groups and combines two types of concern: the welfare of people and 
the welfare of nature. In such context, universalism values correspond well to the notion of CSR, providing the background for exploring the relationship between the two constructs.

Going further, the paper argues that universalism values can drive not only the employee perception of CSB, but also OCB, as values can serve as the explanation of individual behaviour (Schwartz, 2012). While numerous studies have been carried out to examine the different drivers of OCB, the potential of values to foster OCB still requires more attention (SSerban, 2015). Moreover, the paper responds to the call in the management studies to explain the mechanism through which one construct impacts another (Paauwe, 2009), analysing the potential mediating or moderating processes. The paper argues that for universalism values to have an effect on OCB, some other construct could enhance this effect. Following the previous findings (Valentine and Fleischman, 2008), this paper predicts that employee perception of CSR is supposed to play a mediating role in the relationship between the universalism values and OCB.

The aim of this paper is to reveal the linkage between employee perception of CSR, OCB and universalism values. In doing this, the paper seeks to answer the following: how can CSR be defined and why is it important to take the employee perspective into consideration? How can OCB be defined? How values, especially universalism values, could be perceived? Will universalism values drive OCB and employee perception of CSR? Will employee perception of CSR result in a positive effect on employee OCB? Will employee perception of CSR mediate the linkage between the universalism values and employee OCB?

The paper contributes to the literature in several ways. Firstly, the paper adds to the research field, which is calling to apply the employee-centered approach ( Van DeVoorde et al., 2012; Guest, 2017) while exploring the employee concerns. In doing this, the paper focuses on the employee perspective, in terms of CSR, universalism values and OCB. Secondly, for operationalising and better understanding CSR perceived by employees, the following pathways have been generally suggested in the literature: to organise CSR practices by stakeholder types (Park and Levy, 2014), to use a global measure of CSR or to apply CSR practices directed to a single group of stakeholders (Newman et al., 2015). The paper contributes to the first stream by distinguishing between the CSR practices towards different stakeholders. This allows enriching literature not only on CSR, but also on stakeholder management. Thirdly, the paper contributes to the literature by linking the universalism values to the field of human resource management, namely employee extra role behaviour. Finally, the paper is designed to explore the mechanism by which the universalism values influence the employee OCB. Thus, the paper adds value to understanding the linkage between the universalism values and OCB by exploring the mediating effect caused by the employee perception of CSR.

The paper begins by examining the literature on CSR, OCB, and universalism values and developing the hypotheses. The research methodology is then outlined. Following this, the results of the research are presented and discussed. Last, the paper provides several general conclusions before indicating some future research avenues.

\section{Theoretical background}

\section{Corporate social responsibility from stakeholder management perspective}

In recent years, organisations recognised their social responsibility with more clarity and started considering it to be a part of their identity (Commission of the European Communities, 2001). Seeing that CSR can contribute to competitiveness (European Competitiveness Report, 2008), an increasing number of organisations are promoting 
socially responsible initiatives in response to the variety of environmental, social, and economic pressures (Gazzola, 2017; Zbuchea and Pînzaru, 2017) and have CSR agendas (Hejjas et al., 2019).

Although there is no universally accepted definition of CSR (Wang and Juslin, 2011), the Green Paper (Commission of the European Communities, 2001) concludes that most definitions of CSR describe it as a "concept whereby companies integrate social and environmental concerns in their business operations and in their interaction with their stakeholders on a voluntary basis" (p. 8). Seeking clarity and simplicity, more recently, the European Commission (Commission of the European Communities, 2011) provided a new definition of CSR as "the responsibility of enterprises for their impacts on society" (p. 6) and outlined what business should do to meet that responsibility. Clearly, the definitions of CSR have a number of important implications; however, the crucial one is that CSR is about the relationships with stakeholders.

According to Rodrigo and Arenas (2008), today is nearly impossible to discuss CSR without referring to the stakeholders of organisations. The well-known definition of stakeholders treats them as "any individual or group who can affect or is affected by actions, decisions, policies, practices or goals of an organisation" (Freeman, 1984, p. 25). Later, Post et al. (2002) put forward a more precise explanation arguing that the stakeholders of an organisation are "individuals and constituencies that contribute, either voluntarily or involuntarily, to its wealth-creating capacity and activities, and who are therefore its potential beneficiaries and/or risk bearers" (Post et al., 2002, p. 8). Referring to the provided definitions, in the contemporary business environment, the stakeholders are perceived in a much broader sense than shareholders; such interest groups as employees, suppliers, NGOs, customers, the general community etc. belong to stakeholders (Mitchell et al., 1997; Jamali, 2008; Wereda et al., 2016; Trivellas et al., 2019). According to Campbell (2007), organisations operate in a socially responsible manner when they undertake two actions: do not knowingly do anything that harm their stakeholders; and in case of harm, the organisations must rectify it whenever the harm is discovered. However, in reality it is much more complicated to deal with the stakeholders, as they may have competitive demands or diverging views (Trivellas et al., 2019) and some clash of the stakeholder interests may occur (Asif et al., 2013). This, in turn, leads to different classifications of stakeholders (Mitchell et al, 1997; Parmar et al., 2010; Weredaet al., 2016). Regardless of the variety of classifications, the message in literature is absolutely clear: employees must always be perceived as highly relevant stakeholders (Greenwood, 2007; Hejjas et al., 2019). According to Mitchell et al. (1997), employees possess three characteristics, which validate their vital role as stakeholders, namely, legitimacy, power, and urgency. The work of Dima et al. (2017) debates on corporate social responsibility in the educational field, illustrating the partnership established between educational institutions and organizations, these entities uniting their powers to enrich the research sector, generate novel products, carry on explorative inquiries and to develop technological possibilities for a better living.

For the purpose of the paper and for the literature, this research can be useful (Capelli et al., 2019) and it should be highlighted that the real scope of CSR practices and the stakeholder perception of these practices may do not fit. Thus, by arranging and implementing socially responsible initiatives, organisations should assess that the benefits of such initiatives are linked with employee perception of CSR (Costa and Menichini, 2013), which could be defined as "as the degree to which employees perceive an organisation supports CSR activities" (Lee et al., 2013). 


\section{Organisational citizenship behaviour}

The constantly increasing interest in OCB has stemmed from the belief that such behaviour enhances organisational effectiveness (Podsakoff and MacKenzie, 1997; Podsakoff et al., 2009; Majeed et al., 2017; Morales-Sánchez and Pasamar, 2019). Jeong et al. (2019) refer to the synergy effect arguing that for an organisation to function effectively, it is critical that employees should not only perform well on their given tasks but also take initiatives to engage in OCB. Actually, employees increasingly often engage in OCB, seeing that the time spent by managers and employees engaging in OCB has increased by more than $50 \%$ over the past two decades (Cross et al., 2016). Originally defined by Organ (1988), OCB is treated as "individual behaviour that is discretionary, not directly or explicitly recognised by the formal reward system, and in the aggregate promotes the efficient and effective functioning of the organisation" (p. 4). Later, Organ (1997) provided a more precise understanding of OCB referring to the "performance that supports the social and psychological environment in which task performance takes place" (p. 95). According to Bolino and Turnley (2003), employee efforts that go "above and beyond the call of duty" (p. 60) reflect the nature of OCB. Chahal and Mehta (2010) treat OCB as a special type of job behaviour, whereas, according to Organ (1988), OCB represents the "good soldier syndrome". Referring to Lin et al. (2010), OCB is related to extra-role behaviour when employees go beyond the general expectations to promote the effectiveness of the organisation or to benefit others in the organisation.

Drawing on the given definitions, several features of OCB are obvious. First, OCB is discretionary, expressed in voluntary initiatives, goes beyond the role requirements, and is a matter of personal choice (Chahal and Mehta, 2010; Boiral, 2009). Second, OCB represents the special or extra efforts that organisations need from their employees in order to be successful (Bolino and Turnley, 2003). However, for better understanding of OCB it is important to translate the construct into practical examples. In doing this, Lin et al. (2010) argue that volunteering for extra works, helping others in their job, cooperating with others or orienting new staff are cases of OCB. Promoting and protecting the organisation, keeping a positive attitude and tolerating inconveniences at work, following organisational rules even when no one is looking, keeping up with developments in one's field or profession, or taking on additional assignments can also serve as examples of OCB (Bolino and Turnley, 2003). The above-mentioned illustrations of OCB once again support the notion that behaviours are discretionary when employees act outside their formal job descriptions. Summing up, these discretionary behaviours are not explicitly required but are implied; they are not formally rewarded but are informally recognised (Banwo and $\mathrm{Du}, 2020$ ).

\section{Universalism values}

Values have been a core concept in the social sciences since their inception (Schwartz, 2012). Generally, values convey what is important to human beings in their lives (Bardi and Schwartz, 2003). Different definitions of values can be found in the literature. For instance, Rokeach (1973) defined values as enduring beliefs regarding personally or socially preferable specific modes of conduct (instrumental values) or end-states of existence (terminal values), which influence attitudes and behaviours. Schwartz and Bardi (2001) view values as "desirable, transsituational goals, varying in importance, that serve as guiding principles in people's lives" (p. 4). Dhar et al. (2008) argue for values as micro-macro concepts, emphasising that "at the micro level of individual behaviour, values are motivating as internalized standards that reconcile a person's needs with the demands of social life. They allow individuals to evaluate the options that are available 
to them for action. At the macro-level of cultural practices, values represent shared understandings that give meaning, order and integration to social living" (p.183). Drawing on the provided understanding of the concept of values, the most crucial message is that values have been recognised as the key determinants of human attitudes, behaviour and decision-making (Choongo et al., 2018; Črešnar and Nedelko, 2020).

Over the last decade, Schwartz's value theory has been the most widely accepted view in explaining the structure and content of values (Siltaoja, 2006; Wang and Juslin, 2012). Schwartz identified ten value types, which can be further clustered into four value orientations: 1) self-transcendence (altruistic value types of universalism and benevolence), 2) self-enhancement (egoistic values focused on personal power and achievement), 3) openness (including the value types of self-direction, hedonism and stimulation), and 4) conservation (including the tradition, conformity and security value types) (Schwartz, 1992; Schwartz, 1994). The paper limits its focus on one type of values, namely universalism values, as these correspond directly to the core of CSR. The universalism values express such goals as understanding, appreciation, tolerance, and protection for the welfare of all people and for nature (Schwartz et al., 2012; Schwartz, 2015). Universalism values combine two types of concern: first, for the welfare of those in the larger society and world, and second, for nature. These values refer to social justice, equality, world peace, wisdom, unity with nature, broadmindedness, and environmental protection (Schwartz, 2012).

\section{Hypothesis development \\ Employee perception of CSR and OCB}

CSR is a multi-dimensional concept, usually categorised by the aspects of responsibilities or by stakeholders groups (Park and Levy, 2014; Lee et. al., 2012). The previous studies suggest that CSR activities are better understood theoretically and tested empirically when they are organised by stakeholder type (Park and Levy, 2014). Meantime, prior studies on the influence of CSR on employee behaviour (Carmeli et al., 2007; Rupp et al., 2013; Zhang et al., 2014; John et al., 2019) have mainly examined the influence of CSR practices targeted at a single group of stakeholders or used a global measure. To the knowledge of authors the current paper, only several researchers, namely Newman et al. (2015) and Abdullah and Rashid (2012), analysed the employee perception of CSR towards different stakeholders types in relation with OCB. Seeking to close this gap and following the recommendations in the literature, the paper conceptualises the CSR perception in line with Turker (2009b) implying a four-dimensional structure of CSR stakeholders: social and non-social stakeholders, employees, customers, and government.

Social identity theory (SIT) is employed in this paper to explain the relationship between CSR and OCB. SIT proposes that individuals view themselves as members of social groups, including the organisation they work for, and derive either positive or negative self-esteem from such belonging ( Tajfeland Turner, 1985; Hofman and Newman, 2014; Brunetto and Farr-Wharton, 2002). Perceptions of the organisational identity and beliefs held by the members of an organisation may influence the strength of identification of an individual with the particular organisation (Brammer et al., 2007). Generally, organisational identification provides a starting point for employees from which they view and understand "what one should think and feel, and how one should behave" (Hogg et al., 1995, p. 260). Drawing on SIT, the hypotheses are provided below.

\section{CSR towards employees}


This paper argues that employees represent the most critical primary stakeholder group, as they determine the quality of service and goods (Lee et al., 2012) and are agents of a particular employer, at least from the customer perspective (Turker, 2009b). Accordingly, employees are able to take on a more active or passive role by engaging in different CSR initiatives at different times (Hejjas et al., 2019). Encouraging employees to participate in voluntary activities or to develop their skill and career; ensuring worklife balance; treating employees in a fair manner or taking the employee needs and wants seriously indicate that the organisation is socially responsible towards employees (Turker, 2009b). Actually, the mentioned practices are extremely vital for the business success, as they determine the employee well-being, which in turn influences the job performance (Guest, 2017). According to SIT, when employees have positive perceptions that the organisation takes care of them and their colleagues, they are more likely to perceive that the organisation shares similar values to their own and as a result develop a high level of organisational identification (Newman et al., 2015). Moreover, improvement in the working environment of employees is likely to contribute to the organisation's reputation ensuring the label of "good employer" (Hofman and Newman, 2014). As a result of stronger identification with the organisation, employees will be more likely to take the "good soldier" duties.

Despite these theoretical expectations, the empirical evidences are more contradictory than supporting. For instance, Zhang et al. (2014) found a strong relationship between the general measure of employee perceptions of corporate social performance, including the items measuring CSR directed towards employees, and employee OCB. Furthermore, Abdelmotaleb and Saha (2019) revealed that if an employee is treated well in the organisation (for instance, work-life balance, training opportunities, career development) then this is likely to increase the employee's willingness to display OCB and expend discretionary effort to support the organisation. In the meantime, Newman et al. (2015) found no statistically significant relationship between the CSR directed at employees and OCB. Thus, based more on theoretical expectations, the paper hypothesises the following:

\section{H1. Employee perceptions of CSR towards employees will be positively related to their OCB.}

\section{CSR towards customers}

Certainly, customers belong to the most crucial stakeholders of an organisation. In turn, organisation try to build and maintain good relationship with them using plenty of tools, including the CSR initiatives (Turker, 2009a). CSR towards customers manifests itself in a variety of ways, such as protecting consumer rights beyond the legal requirements; providing full and accurate information about products; or treating customer satisfaction as highly important (Turker, 2009b). Employees as the agents of the organisation interact with the customers closely by receiving feedback about services or goods (Newman et al., 2015). Accordingly, employees may feel shame, if the organisation misleads its customers or proud, if the customers were taken care of properly (Turker, 2009b). Drawing on SIT, positive feedback received from the customers should encourage the employee to go "above and beyond the call of duty" for the benefit of others in the organisation. Referring to theoretical expectation and despite the fact that Newman et al. (2015) found no statistically significant relationship between CSR towards customers and employee OCB, the paper proposes the following hypothesis: 
CSR towards social and non-social stakeholders.

This group of stakeholders consists of four types of so-called secondary stakeholders, who are closely interrelated with each other: society, natural environment, future generations and NGOs (Turker, 2009a). Although this group has a less direct impact on organisations, Turker (2009a) argues that these stakeholders may be extremely influential on business and cannot be ignored or underestimated. Being socially responsible towards social and non-social stakeholders refers to such initiatives as: protecting and improving the quality of the natural environment or minimising the negative impact on nature; creating a better life for future generations; promoting the well-being of the society; encouraging sustainable growth, which concerns the future generations; or support for non-governmental organisations (Turker, 2009b). Drawing on SIT, if an organisation attempts to engage in mentioned initiatives, its employees can be proud of working for such organisation and this leads to increased identification with the organisation (Turker, 2009). Moreover, strong organisational identification will lead employees to feel that they share the same values with co-workers and due to this employees will be more likely to engage in extra-role behaviour, not directly or explicitly recognised by the formal reward systems and that benefits other members of the organisation (Newman et al., 2015).

Turning to empirical evidence, Rupp et al. (2013) demonstrated a strong relationship between the employee perception of CSR towards secondary stakeholders and OCB. Such relationship was also supported by Newman et al. (2015) arguing that a favourable employee perception of CSR directed at social and non-social stakeholders was positively and significantly related to employee OCB.

Based on theoretical insights and empirical evidence above, the paper hypothesises the following:

H3. Employee perceptions of CSR towards social and non-social stakeholders will be positively related to their $O C B$.

CSR towards government.

CSR towards government is manifested when an organisation pays taxes and observes the legal regulations completely and promptly (Turker, 2009b). Working for an organisation that meets its obligations under the law will increase the employee level of self-esteem and identification with the values of the organisation. Further, this leads the employees to go above and beyond their job rules in order to help their co-workers with whom they perceive to have similar values (Carmeli et al. 2007; Bartels et al., 2010). Empirical evidence concerning the CSR directed at the impact of government on OCB are scant and do not support the theoretical assumptions, as Newman et al. (2015) found no statistically significant relationship between CSR towards government and employee OCB. Nonetheless, based on theory and the empirical evidence that CSR directed at government has a positive and significant impact on employee attitudes, namely organisational commitment, it is hypothesised:

H4. Employee perceptions of CSR towards government will be positively related to their $O C B$.

The general hypothesis sounds as follows: 


\section{H5. Employee perceptions of CSR will be positively related to their OCB.}

\section{Universalism values and employee perception of CSR}

A theme emerging from the literature states that values affect human perception and behaviour because they contain a judgement element in which they frame social norms and emotions about what is good, right, or desirable (Hemingway, 2005; Wang and Juslin, 2012). As stated by Gandal et al. (2005), "values influence people in their perceptions and interpretations of situations, and hence direct people in their decisions, choices and behaviors" (p. 246). Thus, employee perception of CSR may also be influenced by values. Referring to the universalism value, Gau et al. (2019) argue that those who value equality and world at peace are concerned with disadvantaged people and want to help them, while those who are concerned with nature are more likely to appreciate initiatives regarding environmental protection. Drawing upon the provided explanation, Gau et al. (2019) conclude that people who value universalism are more likely to perceive and support the CSR programmes because of their altruistic focus.

However, literature analysing the linkage between the CSR activities and values is still scant. Hemingway (2005) suggested a theoretical assumption that CSR is not solely driven by economics and that it may also be enhanced as a result of personal morality, inspired by the employees' own socially oriented personal values. Wang and Juslin (2011) found that values had a significant influence on Chinese youth perception of CSR. More recently, González-Rodríguez et al. (2015) demonstrated that values act as drivers of CSR perception for students as potential entrepreneurs. Thus, following the theoretical and empirical evidence, it is hypothesised:

H6. Universalism values will be positively related to employee perceptions of CSR, including CSR towards employees (H6a), CSR towards customers (H6b), CSR towards social and nonsocial stakeholders (H6c), and CSR towards government (H6d).

\section{Relationship of universalism values and OCB}

As it was mentioned before, overt behaviour is a particularly important consequence of values (Bardi and Schwartz, 2003). Among the drivers of OCB, the literature mainly focuses on role perception, individual disposition, fairness perception, leadership, job satisfaction, organisational commitments, and motivation (Chahal and Mehta, 2010). According to the mainstreaming notion, employees who have altruistic concerns will engage in OCB because they care about the well-being of others (Morales-Sánchez and Pasamar, 2019). Considering the universalism values as a motivational construct (Bardi and Schwartz, 2003), the paper proposes the following hypothesis:

\section{H7. Universalism values will be positively related to OCB.}

For better understanding of the relationship between two constructs, it is relevant to perceive the mechanism how the impact occurs. The potential of perceived CSR to play the mediating role is still not widely explored in the literature. Yet, the research done by Valentine and Fleischman (2008) indicated that the perceived CSR plays a mediating role in the relationship between the ethics programmes and job satisfaction. Thus, it is hypothesised as follows:

H8. Employee perception of CSR will mediate the relationship between the universalism values and $O C B$. 
Summing up and following the theoretical insights and the hypotheses, the theoretical model is provided in Figure 1.

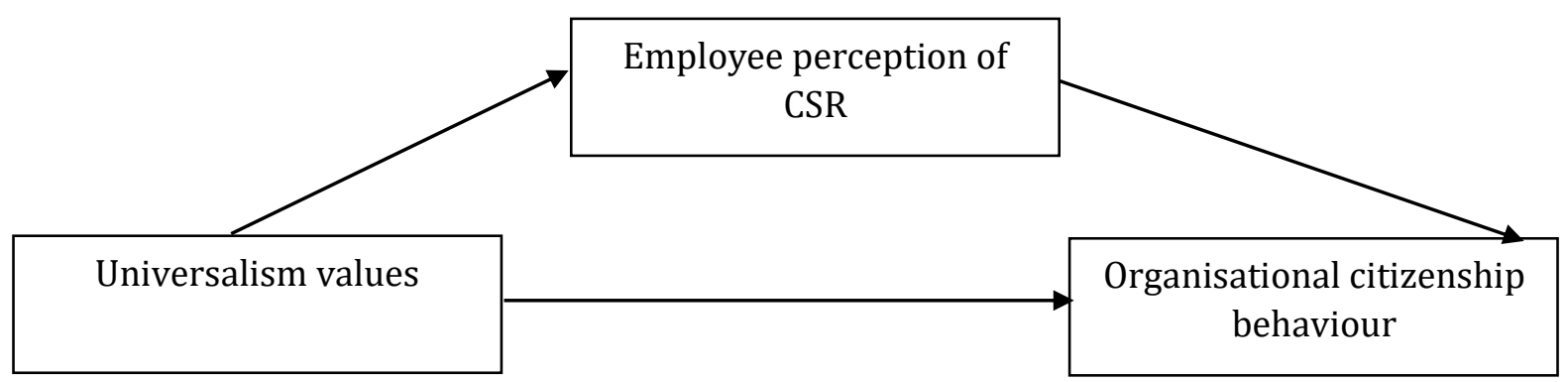

Figure 1. Theoretical model of the research

\section{Research method}

The main objective of the research was to determine the relationships between the employee perceptions of CSR towards four stakeholder groups, universalism values and OCB.

Sample and data collection. Keeping in mind the objective of the research, a nonprobability sampling technique was applied. Nonprobability sampling refers to "a sampling technique where the samples are gathered in a process that does not give all the participants or units in the population equal chances of being included" (Etikan et al., 2016, p. 1). Data were collected using a convenience sampling type from the - employees in Lithuania. Convenience sampling is a type of nonprobability sampling where members of the target population that meet certain practical criteria, such as easy accessibility, availability at a given time, geographical proximity, or the willingness to participate, are included for the purpose of the study (Etikan et al., 2016).

Lithuania was chosen due to several reasons. Firstly, although the country does not have a long tradition of sustainability, the number of organisations, which have committed to sustainability is growing (Stankevičiūtè and Savanevičienè, 2018). Secondly, labour productivity in Lithuania is among the lowest in the EU (OECD, 2018). The current research may provide some evidence that by engaging in CSR, businesses could promote the extra-role behaviour of employees, which in turn might lead to better performance.

Two ways to reach the respondents were chosen. First, questionnaires were distributed via LinkedIn, Facebook and other social networks. Second, the questionnaires were sent to former Human Resource Management study programme students and human resource professionals the authors of the paper collaborate with during the study process, asking them to distribute the questionnaires further. Due to this way of disseminating the questionnaire, it is impossible to estimate the number of persons the questionnaires were sent to and the actual response rate. However, the mentioned two ways allowed spreading the questionnaire to the possibly broadest circle of potential respondents. 
While distributing the questionnaires, the information about the purpose of the survey, instructions and a link to the survey were sent. There were no monetary or nonmonetary rewards for participation, as participants were told that their participation was voluntary and would remain anonymous.

Data collection took more than 2 months. At the end of the research, 301 questionnaires were collected and, according to the number of employees in Lithuania (approx. 1,267,000), such amount of responses reflected an acceptable bias of 5.5\%, which indicated the reliability of the data (confidence level of 95\%).

Table 1 provides the respondents' profile.

Table 1. Respondents' profile

\begin{tabular}{|c|c|c|}
\hline Characteristics & Frequency (n) & Percentage (\%) \\
\hline \multicolumn{3}{|c|}{ Gender } \\
\hline Female & 187 & 62.1 \\
\hline Male & 114 & 37.9 \\
\hline \multicolumn{3}{|c|}{ Age } \\
\hline $18-25$ & 161 & 53.5 \\
\hline $26-32$ & 42 & 14.0 \\
\hline $33-41$ & 34 & 11.3 \\
\hline $42-52$ & 46 & 15.2 \\
\hline $53-65$ & 18 & 6.0 \\
\hline Working time in a particular organisation \\
\hline Up to 1 year & 41 & 13.6 \\
\hline 1-3 years & 64 & 21.3 \\
\hline 3- 5 years & 116 & 38.5 \\
\hline More than 5 years & 80 & 26.6 \\
\hline \multicolumn{2}{|c|}{} \\
\hline
\end{tabular}

Measures. The paper integrates well-established scales. All measures were subjected to reliability analysis. Reability were assessed using Cronbach Alpha coefficient.

OCB was measured using the OCB scale of Podsakoff et al. (1990) (cit. Fields, 2002), which includes 24 items. Respondents were asked to indicate their agreement with each statement on a 5-point Likert scale, where 1 means strongly disagree, 5 strongly agree. The scale had a Cronbach's alpha of 0.851 .

Employee perceptions of organisational CSR was measured using the Turker's (2009a) scale, which comprises 4 subscales: CSR practices towards social and non-social stakeholders (8 items), employees (5 items), customers (3 items), and government (2 items). Respondents were asked to indicate their agreement with each statement on a 5point Likert scale, where 1 means strongly disagree, 5 - strongly agree. The subscales had a Cronbach's alpha of $0.895 ; 0.846 ; 0.711$ and 0.712 respectively.

Universalism values were measured using the Schwartz's (1994) 9 items scale (cit. Fields, 2002). Respondents were asked to indicate their agreement with each statement on a 5-point Likert scale, where 1 means strongly disagree, 5 - strongly agree. The scale had a Cronbach's alpha of 0.868 .

As all Cronbach Alpha coefficients exceeded 0.7, all measures were considered acceptable for analysis (Nunnally, 1978).

\section{Results}

As already identified, the aim of this paper was to explore the relationships between the employee perceptions of CSR towards four stakeholder groups, universalism values and 
OCB. By doing this, the mediating role of employee perception of CSR referring to the linkage between the universalism values and OCB was also analysed.

The means, standard deviations for the scales and correlation matrix are provided in Table 2 .

As expected, employee perception of CSR directed at four main stakeholder groups were related to OCB and universalism values. Universalism values were also related to OCB. To test the study hypotheses, multiple regression analyses were conducted (Table 3). The results are discussed below.

Generally, H1-H5 propose a positive relationship between the employee perception of CSR and OCB. Columns 2-6 of Table 3 show the results of regression analysis. The results indicated that employee perception of CSR towards employees (0.344., $\mathrm{p}<0.001)$; towards customers $(0.406, \mathrm{p}<0.001)$; towards government $(0.350$, $\mathrm{p}<0.001)$ and towards social and non-social stakeholders $(0.161, \mathrm{p}<0.01)$ were predictors of employee engagement. In general, employee perception of CSR had a positive impact on OCB $(0.340, \mathrm{p}<0.001)$. Thus, these results provide the support for $\mathrm{H} 1$, $\mathrm{H} 2, \mathrm{H} 3, \mathrm{H} 4$, and $\mathrm{H} 5$.

H6 suggests a positive relationship between the universalism values and employee perceptions of CSR, namely CSR towards employees (H6a), CSR towards customers (H6b), CSR towards social and non-social stakeholders (H6c), and CSR towards government (H6d). As it was expected and is seen from Columns 7-11 in Table 3, the results provide support for H6, H6a, H6b, H6c, and H6d.

Concerning $\mathrm{H7}$, the results confirmed that the universalism values had a positive relationship on $\operatorname{OCB}(0.333, \mathrm{p}<0.001)$. 


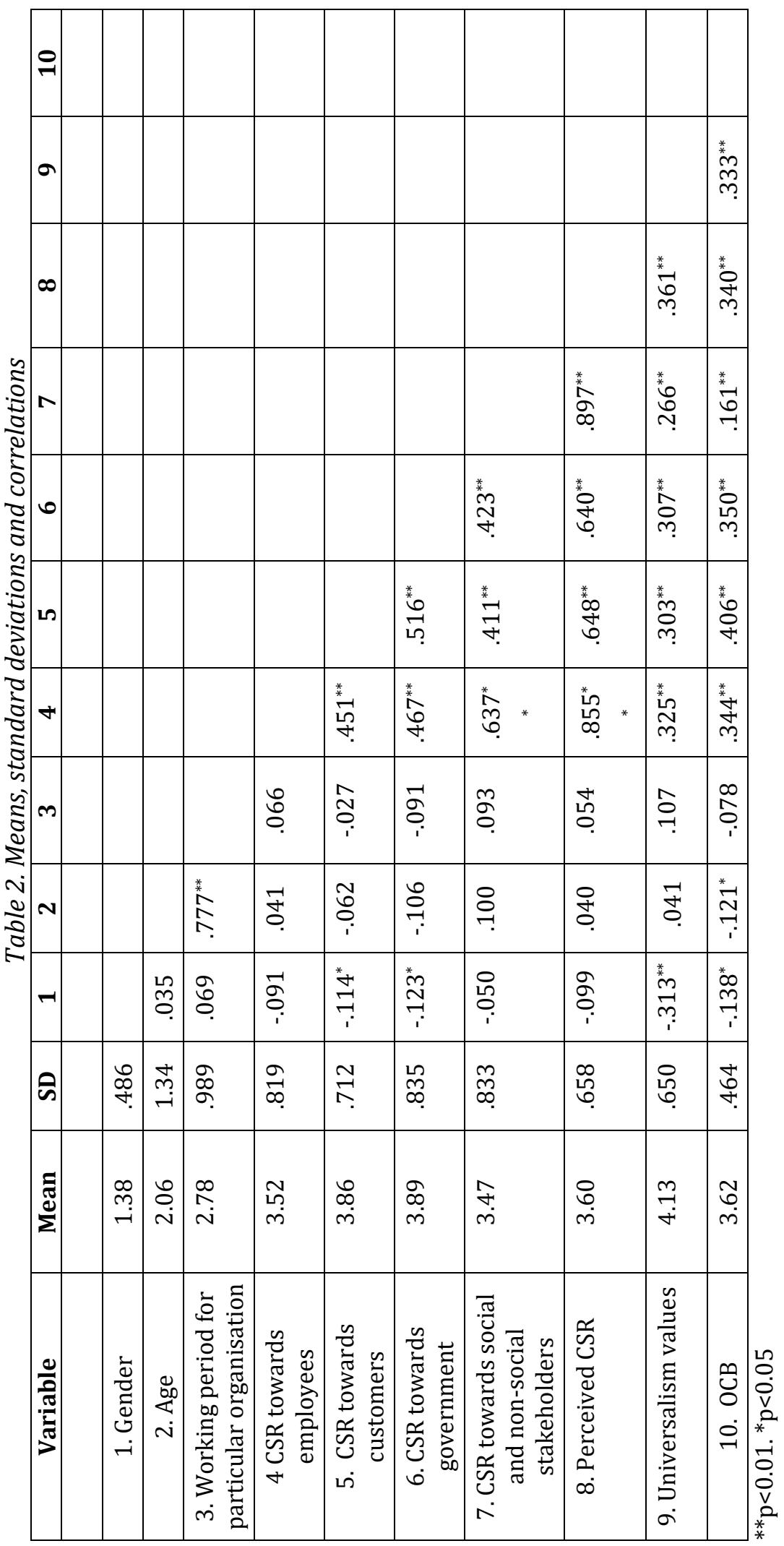




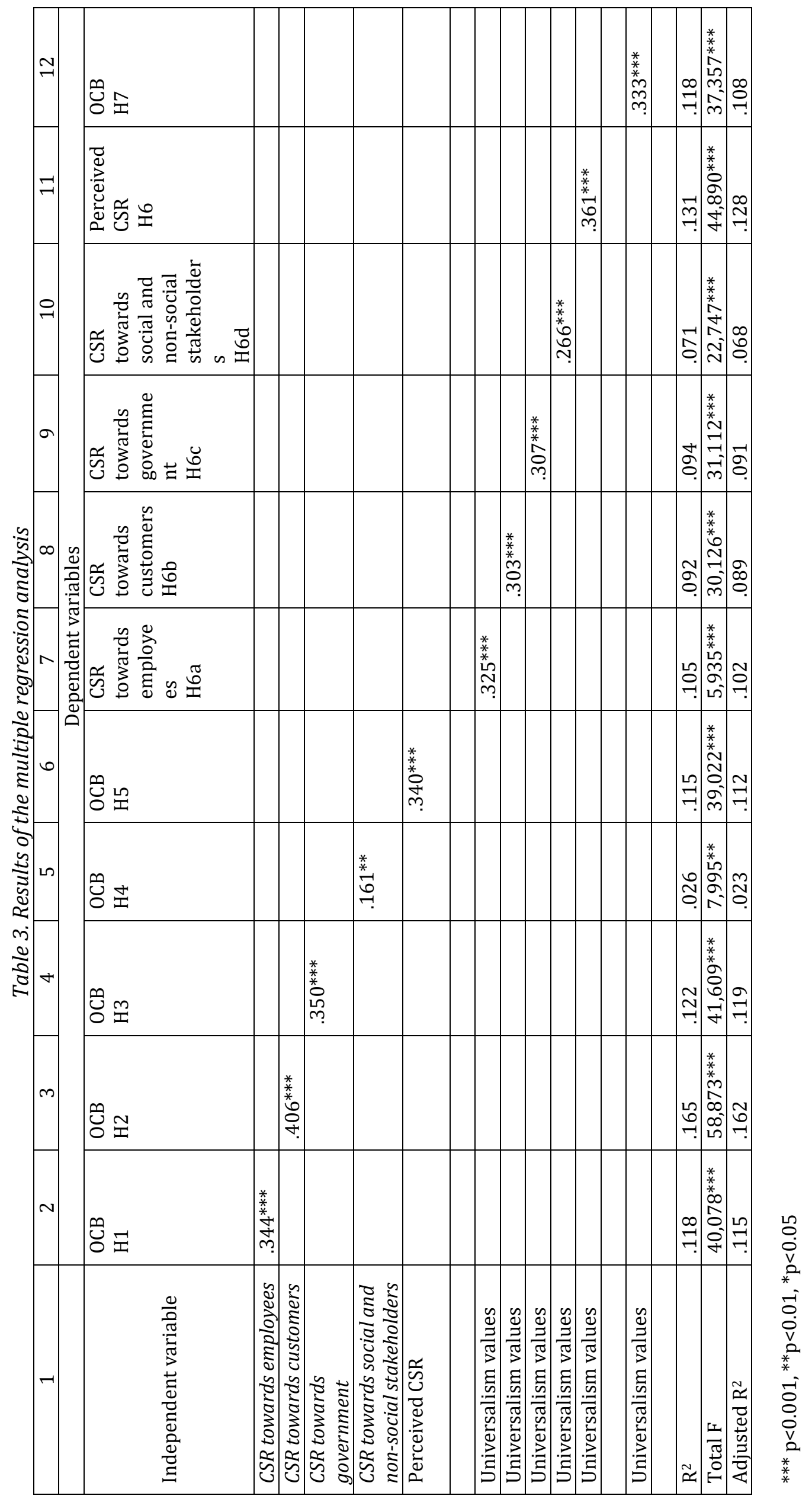


Mediating effects of employee perception of CSR. According to MacKinnon et al. (2000), three conditions must be met to establish mediation. First, the independent variable (in this paper - universalism values) must be related to the mediator (in this case - employee perception of CSR). Second, the mediator (in this paper - employee perception of CSR) must be related to the dependent variable (OCB). Third, a significant relationship between the independent variable (universalism values) and the dependent variable (OCB) must still exist (partial mediation) or be no longer significant (full mediation) when controlling for the mediator (employee perception of CSR).

In order to test the mediation model in which the employee perception of CSR mediates the relationship between the universalism values and OCB, additional regression analyses were conducted (Table 4).

Table 4. Mediating effects of perceived CSR

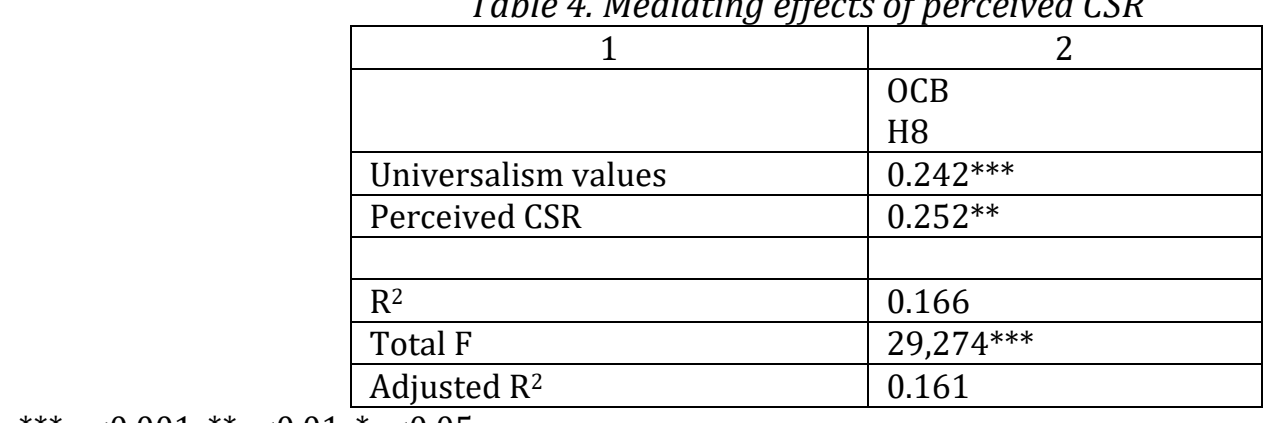

*** $\mathrm{p}<0.001,{ }^{* *} \mathrm{p}<0.01,{ }^{*} \mathrm{p}<0.05$

As is it seen from Table 3 (Column 12) and Table 4 (Column 1), the addition of employee perception of CSR to the equation has increased the variance explained from $11 \%$ to $16 \%$, and the factor of universalism values is further statistically significant at $\mathrm{p}<$ 0.01 , indicating a partial mediation relationship between the universalism values and OCB. Thus, hypothesis H7 was partly confirmed - employee perception of CSR partially mediates the linkage between the universalism values and OCB.

\section{Discussion}

The purpose of this paper was to reveal the relationships between the employee perceptions of CSR towards four stakeholders' groups, universalism values and OCB. In addition, the study was designed to explore the mechanism by which the universalism values influence the OCB of employees.

Overall, all the hypotheses received some support. The results supported all hypotheses raised concerning the $\mathrm{OCB}$, strengthening the basic premise that positive employee perceptions towards different stakeholders will result in higher employee OCB. Moreover, the results supported the hypotheses concerning the notion that the universalism values serve as a predictor of employee perception of CSR and have a positive impact on OCB. A mediating role of employee perception of CSR in the relationship between the universalism values and OCB was identified.

Results referring to the employee perceptions of CSR directed at employees demonstrated the existence of a positive relationship with OCB, emphasising that it pays off to take care of the employees, leading to an increased identification with the organisation. Drawing upon SIT, employees with the higher level of organisational identification are willing to make more of an effort and expend more energy for the good of their organisations (John et al., 2019). While the employees perceive that they are receiving benefits from the organisation, they feel the need to give something back 
(Farid et al., 2019), and this "something back" manifests as OCB. The empirical findings are in accordance with the conclusion recently drawn by Trivellas et al. (2019) about the strong association between the social dimension of employee perception of CSR and OCB in the case of a Greek port logistics management services organisation. However, the received results contradict the findings of Newman et al. (2015), when the hypothesis that the employee perception of CSR directed to employees had a positive influence on OCB was not confirmed. This discrepancy might be explained by different working settings, as one research was carried out in China, another in Lithuania. Still, more recently the study in China in hospitality business revealed a significant and indirect relationship between CSR (including CSR directed at employees) and OCB (He et al., 2019). Thus, generally, the findings strongly support the overall notion that employees are the core stakeholders of organisations and taking the employee concerns seriously is a key target of each private or public organisation willing to survive in the long-term (Guest, 2017). This might be considered by businesses both in more or less stable periods and in times of crises seeing that employee behaviours that go above and beyond the call of duty are beneficial to the organisation and can contribute to performance and competitive advantage (Morales-Sánchez and Pasamar, 2019).

Consistent with the expectations, the findings revealed that the perceived CSR towards customers results in a higher level of OCB. Such results support the idea that each employee interacts closely with the customers and interprets the feedback from them on organisation's actions directed towards the customers as well as consequences of such actions (Turker, 2009b). The employees share the organisational success or failure referring to positive or negative feedback from satisfied or unsatisfied customers. It seems that better treatment of customers impels the employees towards the behaviour that goes above and beyond the call of duty (Bolino and Turnley, 2003). As in the previous case, the findings of the paper are inconsistent with the findings of Newman et al. (2015), who found no statistically significant relationship between the CSR towards customers and OCB, but this might be explained by different working settings.

Consistent with theoretical expectations, employee perceptions of CSR directed at government were found to be positively related to OCB. Such findings contradict the empirical findings of the study carried out in China (Newman et al., 2005). However, considering that some businesses in Lithuania and other EU countries still do not follow the legal requirements and try to avoid paying taxes or to pay less, the employees are more willing to work for organisations, which are more socially responsible and, accordingly, to put extra efforts, resulting in OCB.

As it was predicted, a positive relationship between employee perceptions of CSR directed at social and non-social stakeholders with OCB was found. These findings are in line with the study of Rupp et al. (2013), where the employees' CSR perceptions directed at community relations concerns and environmental sustainability concerns were found to be positively related to their OCB. In addition, the paper supports the findings of Newman et al. (2015) emphasising that attention to the needs of the society, next generation and non-governmental organisations, and also care for the natural environment may reap beneficial results for organisations in terms of having employees with increased identification with the organisation. Further, the findings are in accordance with the research of Trivellas et al. (2019) demonstrating the positive impact of the environmental dimension of employee perception of CSR referring to OCB. According to SIT, if an organisation invests in CSR towards external social and non-social stakeholders, this should strengthen the pride felt by employees due to their being 
members of that organisation (Turker, 2009b). The pride may result in employee willingness to put extra efforts and do more than written in the job description. Furthermore, it is important to underline that the same positive relationship was found in different geographic contexts: China (Newman et al., 2015) and Lithuania. Thus, the findings strengthen the notion that the employees are concerned about future generations, natural environment, and life of society in whole. More specifically, the feeling of employees that the organisation cares "about the present and future of world" (Turker, 2009b, p. 192) results in increased identification with the organisation, which fosters extra-role behaviour.

However, more recently study of Abdelmotaleb and Saha (2019) conducted among the public sector employees demonstrated that external CSR perceptions (including environmental activities) had no direct relationship with the employee OCB. This was explained by evidence that external CSR (especially discretionary and environmental activities) is perceived as less important by employees working in the developing economies than those working in developed economies (Abdelmotaleb and Saha, 2019). Returning to the findings of this paper, it seems that environmental issues matter for the research sample implying that employee perception of the employer showing commitment to "green" issues serves as a driver for OCB.

Continuing the discussion as to whether the values could drive the employee perception of CSR, this research has shown that the universalism values enhance the employee perception of CSR. More specifically, if employees care about the environment protection, beauty of the world, unity with nature, broad-mindedness, social justice, wisdom, equality, and inner harmony, and peace in the world is personally important to them, this strengthens their perception of CSR. As it was mentioned, the universalism values derive from the need to survive; it is just that people do not recognise this need until they encounter others and until they become aware of the scarcity of natural resources (Schwartz, 2012). Thus, universalism values and CSR have much in common, seeing that environment-friendly solutions and practices enhancing social welfare are at the core of both. The current findings do not support the results of the study by Wang and Juslin (2011) where young Chinese people, who valued self-enhancement (including universalism values) more, had a more negative perception of the CSR performance of Chinese corporations. Certainly, people who care more about acceptance, tolerance, and concern for all people regardless of the group membership (Gandal et al., 2005) may judge the organisation's CSR activities more strictly, however they may be aware and understand that real initiatives (not "greenwashing"), regardless of them being modest and few, lead to sustainable development. In such context, universalism values could have a positive influence on employee perception of CSR, as it is the case in the present study.

Further, the paper contributes to the research field by exploring the drivers of OCB. Bolino et al. (2002) concluded that prior research indicates that individuals are most likely to engage in OCB when "they are satisfied with their jobs or committed to their organisations, when they are given intrinsically satisfying tasks to complete, and/or when they have supportive or inspirational leaders" (p. 505). The paper took a slightly different approach arguing that overt behaviour is a particularly important consequence of values (Bardi and Schwartz, 2003). Consequently, universalism values were supposed to be positively related to OCB. This assumption was confirmed broadening the spectrum of drivers of OCB (Chahal and Mehta, 2010). In addition, the research revealed that employee perception of CSR partly mediates the relation between the universalism values and employee OCB. In summing up, all the mentioned findings 
indicate the need for business to follow a complex approach when evaluating the relationship between the employee perception of CSR, universalism values and employee OCB.

\section{Conclusions}

The paper aimed at exploring the relationship between the employee perception of CSR, their OCB and universalism values. The results demonstrated that employee perceptions of organisations implementing socially responsible practices towards employees, customers, government, and social and non-social stakeholders lead to a greater exhibition of OCB by employees. Next, the results support the idea that the universalism value may enhance both the employee perception of CSR and employee OCB. Further, it was revealed that employee perception of CSR partly mediates in the relationship between the universalism values and OCB.

The paper provides several practical implications. Firstly, practitioners will benefit from considering CSR in order to foster the employee OCB, seeing that the employee perception of the organisation acting in a socially responsible way towards various stakeholder groups results in extra-role employee behaviour. Secondly, practitioners should employ the notion that universalism vales act as drivers for employee perception of CSR. In this context, González-Rodríguez et al. (2015) suggested for the organisations to prepare a detailed plan for the CSR activities and align the activities with particular values. Such recommendation could be also valid in the case of employee OCB. Finally, the main practical implication to emerge from the current research is that businesses willing to reap the benefits from CSR should not only evaluate how the implemented activities are perceived, but also should not neglect the perceptions of employees as highly salient stakeholders.

The paper has certain limitations that suggest the directions for future research. It might be impossible to generalise the outcomes of the research to other geographic contexts. A study including employees from different countries might yield the results that could be transferable outwards. Another limitation refers to the fact that only universalism values were included in the research. For better understanding if and how the values predict the employee perception of CSR and employee OCB, the whole Schwartz's value theory should be included. A yet another limitation is related to methodology, as the paper did not control the extent to which the employees were involved in CSR initiatives. It could be possible that the involvement level predicts the perceptions of employees, and further, the relationship between the perceived CSR and employee OCB.

In conclusion, this paper challenges the researchers and managers to move towards more sophisticated assessments as to how and why values, CSR and employee OCB are related, seeing that proper understanding of relationships enables the business to move towards organisational sustainability.

\section{References}

Abdelmotaleb, M., \& Saha, S. K. (2019). Corporate Social Responsibility, Public Service Motivation and Organizational Citizenship Behavior in the Public Sector. International Journal of Public Administration, 42(11), 929-939.

Abdullah, M. H., \& Rashid, N. R. N. A. (2012). The implementation of corporate social responsibility (CSR) programs and its impact on employee organizational citizenship behavior. International Journal of Business and Commerce, 2(1), 67-75. 
Asante Boadi, E., He, Z., Bosompem, J., Opata, C. N., \& Boadi, E. K. (2019). Employees' perception of corporate social responsibility (CSR) and its effects on internal outcomes. The Service Industries Journal, 1-23.

Asif, M., Searcy, C., Zutshi, A., \& Fisscher, O. A. (2013). An integrated management systems approach to corporate social responsibility. Journal of cleaner production, 56, 7-17.

Banwo, A. O., \& Du, J. (2020). When the good outweighs the bad: organizational citizenship behaviour (OCB) in the workplace. Human Resource Development International, 23(1), 88-97.

Bardi, A., \& Schwartz, S. H. (2003). Values and behavior: Strength and structure of relations. Personality and social psychology bulletin, 29(10), 1207-1220.

Bartels, J., Peters, O., de Jong, M., Pruyn, A., \& van der Molen, M. (2010). Horizontal and vertical communication as determinants of professional and organisational identification. Personnel Review, 39(2), 210-226.

Bhattacharya, C. B., Korschun, D., \& Sen, S. (2009). Strengthening stakeholder-company relationships through mutually beneficial corporate social responsibility initiatives. Journal of Business ethics, 85(2), 257-272.

Bhattacharya, C. B., \& Sen, S. (2004). Doing better at doing good: When, why, and how consumers respond to corporate social initiatives. California management review, $47(1), 9-24$.

Boiral, O. (2009). Greening the corporation through organizational citizenship behaviors. Journal of Business Ethics, 87(2), 221-236.

Bolino, M. C., \& Turnley, W. H. (2003). Going the extra mile: Cultivating and managing employee citizenship behavior. Academy of Management Perspectives, 17(3), 6071.

Bolino, M. C., Turnley, W. H., \& Bloodgood, J. M. (2002). Citizenship behavior and the creation of social capital in organizations. Academy of management review, 27(4), 505-522.

Brammer, S., Millington, A., \& Rayton, B. (2007). The contribution of corporate social responsibility to organizational commitment. The International Journal of Human Resource Management, 18(10), 1701-1719.

Brunetto, Y., \& Farr-Wharton, R. (2002). Using social identity theory to explain the job satisfaction of public sector employees. International journal of public sector management, 15(7), 534-551.

Campbell, J. L. (2007). Why would corporations behave in socially responsible ways? An institutional theory of corporate social responsibility. Academy of management Review, 32(3), 946-967.

Cappelli, L., D'Ascenzo, F., Ruggieri, R., Rossetti, F., \& Scalingi, A. (2019). The attitude of consumers towards Made in Italy products. An empirical analysis among Italian customers. Management \& Marketing - Challenges for the Knowledge Society, 14(1), 31-47. https://doi.org/10.2478/mmcks-2019-0003.

Carmeli, A., Gilat, G., \& Waldman, D. A. (2007). The role of perceived organizational performance in organizational identification, adjustment and job performance. Journal of Management Studies, 44(6), 972-992.

Chahal, H., \& Mehta, S. (2010). Antecedents and consequences of organisational citizenship behaviour (OCB): A conceptual framework in reference to health care sector. Journal of Services Research, 10(2), 25. 
Choongo, P., Paas, L. J., Masurel, E., van Burg, E., \& Lungu, J. (2018). Entrepreneurs' personal values and CSR orientations: evidence from SMEs in Zambia. Journal of Small Business and Enterprise Development.

Commission of European Communities (2001). Green Paper. Promoting a European network for corporate social responsibility.

Commission of European Communities (2011). A renewed EU strategy 2011-14 for Corporate Social Responsibility.

Costa, R., \& Menichini, T. (2013). A multidimensional approach for CSR assessment: The importance of the stakeholder perception. Expert Systems with Applications, 40(1), 150-161.

Cross, R., Rebele, R., \& Grant, A. (2016). Collaborative overload. Harvard Business Review, 94(1), 16.

Črešnar, R., \& Nedelko, Z. (2020). Understanding Future Leaders: How are Personal Values of Generations Y and Z Tailored to Leadership in Industry 4.0?. Sustainability, 12(11), 4417.

Dima, A.M., Hadad, S., \& Luchian, I. (2017). Review on the dimensions of businessuniversity alliances. Proceedings of the International Conference on Business Excellence, 11(1), 64-73.

Dhar, U., Parashar, S., \& Tiwari, T. (2008). Profession and dietary habits as determinants of perceived and expected values: an empirical study. Journal of human values, 14(2), 181-190.

Etikan, I., Musa, S. A., \& Alkassim, R. S. (2016). Comparison of convenience sampling and purposive sampling. American journal of theoretical and applied statistics, 5(1), 14.

European Competitiveness Report (2008). European Communities, 2009.

Farid, T., Iqbal, S., Ma, J., Castro-González, S., Khattak, A., \& Khan, M. K. (2019). Employees' perceptions of CSR, work engagement, and organizational citizenship behavior: The mediating effects of organizational justice. International journal of environmental research and public health, 16(10), 1731.

Fields, D. L. (2002). Taking the measure of work: A guide to validated scales for organizational research and diagnosis. Sage.

Freeman, R. E. (1984). Stakeholder management: a strategic approach. New York: Pitman.

Gandal, N., Roccas, S., Sagiv, L., \& Wrzesniewski, A. (2005). Personal value priorities of economists. Human Relations, 58(10), 1227-1252.

Gau, L. S., Huang, J. C., Chen, M. I., \& Naylor, M. (2019). Team Social Responsibility Embedded in Correlates of Universalism Values, Sport Involvement, and Team Identification for Sustainable Management in Sporting Settings. Sustainability, 11(19), 5416.

Gazzola, P. (2017). Corporate Social Responsibility: Drivers, Triggers and Strategies. Management Dynamics in the Knowledge Economy, 5(3), 333-335.

González-Rodríguez, M. R., \& Díaz-Fernández, M. C. (2020). Customers' corporate social responsibility awareness as antecedent of repeat behaviour intention. Corporate Social Responsibility and Environmental Management, 27(3), 1294-1306.

González-Rodríguez, M. R., Díaz-Fernández, M. C., \& Simonetti, B. (2015). The social, economic and environmental dimensions of corporate social responsibility: The role played by consumers and potential entrepreneurs. International Business Review, 24(5), 836-848. 
Greenwood, M. (2007). Stakeholder engagement: Beyond the myth of corporate responsibility. Journal of Business ethics, 74(4), 315-327.

Guest, D. E. (2017). Human resource management and employee well-being: Towards a new analytic framework. Human Resource Management Journal, 27(1), 22-38.

He, J., Zhang, H., \& Morrison, A. M. (2019). The impacts of corporate social responsibility on organization citizenship behavior and task performance in hospitality. International Journal of Contemporary Hospitality Management.

Hejjas, K., Miller, G., \& Scarles, C. (2019). “It's like hating puppies!” Employee disengagement and corporate social responsibility. Journal of Business Ethics, 157(2), 319-337.

Hemingway, C. A. (2005). Personal values as a catalyst for corporate social entrepreneurship. Journal of business ethics, 60(3), 233-249.

Hogg, M. A., Terry, D. J., \& White, K. M. (1995). A tale of two theories: A critical comparison of identity theory with social identity theory. Social psychology quarterly, 255-269.

Hofman, P. S., \& Newman, A. (2014). The impact of perceived corporate social responsibility on organizational commitment and the moderating role of collectivism and masculinity: Evidence from China. The International Journal of Human Resource Management, 25(5), 631-652.

Jamali, D. (2008). A stakeholder approach to corporate social responsibility: A fresh perspective into theory and practice. Journal of business ethics, 82(1), 213-231.

Jeong, Y., Kim, E., Kim, M., \& Zhang, J. J. (2019). Exploring Relationships among Organizational Culture, Empowerment, and Organizational Citizenship Behavior in the South Korean Professional Sport Industry. Sustainability, 11(19), 5412.

John, A., Qadeer, F., Shahzadi, G., \& Jia, F. (2019). Getting paid to be good: How and when employees respond to corporate social responsibility?. Journal of cleaner production, 215, 784-795.

Kong, Y., Antwi-Adjei, A., \& Bawuah, J. (2020). A systematic review of the business case for corporate social responsibility and firm performance. Corporate Social Responsibility and Environmental Management, 27(2), 444-454.

Lee, Y. K., Lee, K. H., \& Li, D. X. (2012). The impact of CSR on relationship quality and relationship outcomes: A perspective of service employees. International Journal of Hospitality Management, 31(3), 745-756.

Lee, E. M., Park, S. Y., \& Lee, H. J. (2013). Employee perception of CSR activities: Its antecedents and consequences. Journal of business research, 66(10), 1716-1724.

Lin, C. P., Lyau, N. M., Tsai, Y. H., Chen, W. Y., \& Chiu, C. K. (2010). Modeling corporate citizenship and its relationship with organizational citizenship behaviors. Journal of Business Ethics, 95(3), 357-372.

MacKinnon, D. P., Krull, J. L., \& Lockwood, C. M. (2000). Equivalence of the mediation, confounding and suppression effect. Prevention science, 1(4), 173-181.

Majeed, N., Ramayah, T., Mustamil, N., Nazri, M., \& Jamshed, S. (2017). Transformational leadership and organizational citizenship behavior: Modeling emotional intelligence as mediator. Management \& Marketing, 12(4), 571-590.

Matten, D., \& Moon, J. (2020). Reflections on the 2018 Decade Award: The Meaning and Dynamics of Corporate Social Responsibility. Academy of Management Review, 45(1), 7-28.

Mitchell, R. K., Agle, B. R., \& Wood, D. J. (1997). Toward a theory of stakeholder identification and salience: Defining the principle of who and what really counts. Academy of management review, 22(4), 853-886. 
Moisescu, O. I. (2015). Demographics-based differences in the relationship between perceived CSR and customer loyalty in the dairy products market. Management \& Marketing, 10(2), 118-131.

Morales-Sánchez, R., \& Pasamar, S. (2019). How to improve organisational citizenship behaviour by combining ability, motivation and opportunity. Employee Relations: The International Journal.

Newman, A., Nielsen, I., \& Miao, Q. (2015). The impact of employee perceptions of organizational corporate social responsibility practices on job performance and organizational citizenship behavior: Evidence from the Chinese private sector. The International Journal of Human Resource Management, 26(9), 1226-1242.

Nguyen, P. A., Kecskés, A., \& Mansi, S. (2020). Does corporate social responsibility create shareholder value? The importance of long-term investors. Journal of Banking \& Finance, 112, 105217.

Nunnally, J. C. (1978). Psychometric Theory (2d ed). McGraw-Hill.

Öberseder, M., Schlegelmilch, B. B., Murphy, P. E., \& Gruber, V. (2014). Consumers' perceptions of corporate social responsibility: Scale development and validation. Journal of Business Ethics, 124(1), 101-115.

OECD (2018). Lithuania Economic Snapshot. Retrieved from http://www.oecd.org/economy/economic-survey-lithuania.htm.

Organ, D. W. (1988). Organizational citizenship behavior: The good soldier syndrome.Lexington Books Lexington. MA Google Scholar.

Organ, D. W. (1997). Organizational citizenship behavior: It's construct clean-up time. Human performance, 10(2), 85-97.

Paauwe, J. (2009). HRM and performance: Achievements, methodological issues and prospects. Journal of Management studies, 46(1), 129-142.

Parmar, B. L., Freeman, R. E., Harrison, J. S., Wicks, A. C., Purnell, L., \& De Colle, S. (2010). Stakeholder theory: The state of the art. The academy of management annals, $4(1), 403-445$.

Park, J., Lee, H., \& Kim, C. (2014). Corporate social responsibilities, consumer trust and corporate reputation: South Korean consumers' perspectives. Journal of Business Research, 67(3), 295-302.

Park, S. Y., \& E. Levy, S. (2014). Corporate social responsibility: perspectives of hotel frontline employees. International Journal of Contemporary Hospitality Management, 26(3), 332-348.

Peloza, J., \& Shang, J. (2011). How can corporate social responsibility activities create value for stakeholders? A systematic review. Journal of the academy of Marketing Science, 39(1), 117-135.

Podsakoff, P. M., \& MacKenzie, S. B. (1997). Impact of organizational citizenship behavior on organizational performance: A review and suggestion for future research. Human performance, 10(2), 133-151.

Podsakoff, P. M., MacKenzie, S. B., Paine, J. B., \& Bachrach, D. G. (2000). Organizational citizenship behaviors: A critical review of the theoretical and empirical literature and suggestions for future research. Journal of management, 26(3), 513-563.

Podsakoff, N. P., Whiting, S. W., Podsakoff, P. M., \& Blume, B. D. (2009). Individual-and organizational-level consequences of organizational citizenship behaviors: A meta-analysis. Journal of applied Psychology, 94(1), 122.

Post, J. E., Preston, L. E., \& Sachs, S. (2002). Managing the extended enterprise: The new stakeholder view. California management review, 45(1), 6-28. 
Rodrigo, P., \& Arenas, D. (2008). Do employees care about CSR programs? A typology of employees according to their attitudes. Journal of Business Ethics, 83(2), 265-283.

Rokeach, M. (1973). The nature of human values. Free press.

Rupp, D. E., Shao, R., Thornton, M. A., \& Skarlicki, D. P. (2013). Applicants' and employees' reactions to corporate social responsibility: The moderating effects of first-party justice perceptions and moral identity. Personnel Psychology, 66(4), 895-933.

Şerban, A. D. (2015). How Personal Values Influence Romanian CSR Managers Involvment in CSR Campaigns. Management Dynamics in the Knowledge Economy, 3(4), 729-748.

Schwartz, S. H. (2015). Basic individual values: Sources and consequences. Handbook of value, 63-84.

Schwartz, S. H. (2012). An overview of the Schwartz theory of basic values. Online readings in Psychology and Culture, 2(1), 11.

Schwartz, S. H., Cieciuch, J., Vecchione, M., Davidov, E., Fischer, R., Beierlein, C., ... \& Dirilen-Gumus, O. (2012). Refining the theory of basic individual values. Journal of personality and social psychology, 103(4), 663.

Schwartz, S. H. (1994). Are there universal aspects in the structure and contents of human values?. Journal of social issues, 50(4), 19-45.

Schwartz, S. H. (1992). Universals in the content and structure of values: Theoretical advances and empirical tests in 20 countries. In Gawronski, B. (Ed.). Advances in experimental social psychology (pp. 1-65). Academic Press.

Schwartz, S. H., \& Bardi, A. (2001). Value hierarchies across cultures: Taking a similarities perspective. Journal of cross-cultural Psychology, 32(3), 268-290.

Siltaoja, M. E. (2006). Value priorities as combining core factors between CSR and reputation-a qualitative study. Journal of Business Ethics, 68(1), 91-111.

Stankevičiūtè, Ž., \& Savanevičienè, A. (2018). Raising the Curtain in People Management by Exploring How Sustainable HRM Translates to Practice: The Case of Lithuanian Organizations. Sustainability, 10(12), 4356.

Tajfel, H., \& Turner, J. C. (1985). The Social Identity Theory of Intergroup Behavior. In Worchel, S., Austin, W.G. (Eds.). Psychology of Intergroup Relations (2 $2^{\text {nd }}$ edition) (pp. 7-24). Chicago: Nelson Hall. Trivellas, P., Rafailidis, A., Polychroniou, P., \& Dekoulou, P. (2019). Corporate social responsibility (CSR) and its internal consequences on job performance. International Journal of Quality and Service Sciences.

Turker, D. (2009a). Measuring corporate social responsibility: A scale development study. Journal of business ethics, 85(4), 411-427.

Turker, D. (2009b). How corporate social responsibility influences organizational commitment. Journal of Business Ethics, 89(2), 189.

Valentine, S., \& Fleischman, G. (2008). Ethics programs, perceived corporate social responsibility and job satisfaction. Journal of business ethics, 77(2), 159-172.

Van De Voorde, K., Paauwe, J., \& Van Veldhoven, M. (2012). Employee well-being and the HRM-organizational performance relationship: a review of quantitative studies. International Journal of Management Reviews, 14(4), 391-407.

Wang, L., \& Juslin, H. (2011). The effects of value on the perception of corporate social responsibility implementation: A study of Chinese youth. Corporate Social Responsibility and Environmental Management, 18(4), 246-262.

Wang, L., \& Juslin, H. (2012). Values and corporate social responsibility perceptions of Chinese university students. Journal of Academic Ethics, 10(1), 57-82. 
Wereda, W., Paliszkiewicz, J. O., Lopes, I. T., Woźniak, J., \& Szwarc, K. (2016). Intelligent Organization (IO): Towards Contemporary Trends in the Process of ManagementSelected Aspects. Radakcja Wydawnictw Wojskowej Akademii Technicznej.

Zbuchea, A., \& Pînzaru, F. (2017). Tailoring CSR Strategy to Company Size?. Management Dynamics in the Knowledge Economy, 5(3), 415-437.

Zhang, M., Di Fan, D., \& Zhu, C. J. (2014). High-performance work systems, corporate social performance and employee outcomes: Exploring the missing links. Journal of Business Ethics, 120(3), 423-435. 